\title{
Simulasi Pemodelan Numerik Hidrodinamika dan Aliran Sedimen pada Bendung PLTA Musi - Bengkulu
}

\author{
Asep Irwan ${ }^{1 *}$, Dimas Setiya Gunawan ${ }^{2}$, Martin Wahyunus ${ }^{3}$, Hadi Mulyanto ${ }^{3}$ \\ Teknik Sipil, Fakultas Teknik dan Desain, Institut Teknologi Sains Bandung, Kabupaten Bekasi, Indonesia \\ 2. Alumni Magister Teknik Kelautan, Fakultas Teknik Sipil dan Lingkungan, Institut Teknologi Bandung, Kota Bandung, Indonesia \\ Unit Layanan PLTA Musi, PT PLN (Persero), Kabupaten Kepahiang, Indonesia \\ *E-mail: asepirwan.marine@gmail.com
}

Informasi naskah:

Diterima

30 Juni 2020

Direvisi

15 Agustus 2020

Disetujui terbit

20 Agustus 2020

Diterbitkan

31 Agustus 2020

\begin{abstract}
This research aims to identify Hydro-Power Plant (PLTA) sedimentation in Musi-River, Bengkulu, Indonesia. Based on field observation and simulation modeling Surface Modeling System 8.01. High sediment levels cause accumulation of reservoirs and loss of direct storage, which in turn causes loss of production potential for the Musi Hydro-Power Plant, Bengkulu. The data used in this modeling are bathymetry, current velocity of measurement results, water level, and grain size of sediment. Based on field observations, it was found that basic sediment types were dominated by silt and sand. The highest elevated sediment content values of $0.166 \mathrm{gr} / \mathrm{l}$, current velocity in the upstream was $0.54-0.61 \mathrm{~m} / \mathrm{s}$ while the middle section was $0.43 \mathrm{~m} / \mathrm{s}$. After the hydrodynamic model is carried out, then the sedimentation model has values that vary throughout the area model, this is influenced by several factors, one of which is the current movement that can affect the amount of water bottom friction. Volume of sediments obtained in the weirs at the PLTA Musi is $211,588 \mathrm{~m}^{3}$ during the simulation of 1 month if multiplied in 1 year, then it obtained $2539,056 \mathrm{~m}^{3}$. From the results of this research, PLTA Musi must prevent this sedimentation by making sediment traps in the upstream.
\end{abstract}

Keywords: Musi Hydro-Power Plant, Sedimentation, SMS 8.01

\section{PENDAHULUAN}

Sedimentasi merupakan suatu peristiwa alam atau proses pengendapan partikel-partikel sedimen yang membentuk menjadi satu kesatuan dan mengendap pada dasar perairan. Dalam waktu yang lama proses sedimentasi ini akan menimbulkan pendangkalan yang cukup signifikan, sehingga jika tidak ditangani secara bertahap maka kapasitas air pada bendung akan berkurang oleh volume sedimen ${ }^{1)}$. Mekanisme pengangkutan sedimen butirbutir tanah yang di bawah dalam air yang mengalir dapat digolongkan menjadi beberapa bagian, yaitu wash load atau sedimen bersih, suspended load transport atau angkutan sedimen melayang, salation load transport atau angkutan sedimen loncat, dan bed load 
transport atau angkutan sedimen dasar ${ }^{2}$. Pembangkit Listrik Tenaga Air Musi merupakan pembangkit listrik dengan tipe Run of River, dengan bangunan pembangkit berada $400 \mathrm{~m}$ di bawah tanah yang memanfaatkan aliran Sungai Musi. Jika saluran yang menuju turbin ataupun reservoir tertutup oleh sedimen, maka energi listrik yang dibangkitkan menjadi lebih rendah karena kapasitas air berkurang oleh volume sedimen yang terdapat di saluran intake maupun reservoir. Begitu pula apabila sedimen atau endapan sampai masuk ke turbin, dapat mengakibatkan kerusakan pada turbin PLTA Musi. Pada tahun 2014 potensi erosi tanah yang terjadi di daerah tangkapan air PLTA Musi mencapai 13,45 ton/ha/tahun atau sebesar 1.737.884,27 ton/tahun secara keseluruhan yang lebih besar dua kali lipat dari erosi yang dapat ditolerir yaitu sebesar 811.804.475 ton/tahun, sedangkan untuk jumlah sedimentasi di daerah tangkapan air PLTA Musi mencapai 137.252,857 ton/tahun juga lebih dari dua kali lipat sedimentasi yang dapat ditoleransi yaitu sebesar 64.132,55 ton/tahun ${ }^{3)}$. Untuk menanggulangi masalah tersebut, pihak PT. PLN (Unit Layanan PLTA Musi) telah melakukan kegiatan flushing. Pelaksanaan flushing diharapkan mampu menghemat biaya pengerukan. Tujuan pelaksanaan flushing adalah mengurangi jumlah sedimen sebelum intake dan meningkatkan efektivitas operasional PLTA. Dalam proses flushing pintu bendungan dibuka dan tingkat air diturunkan, hal ini menyebabkan peningkatan kecepatan air di waduk yang akan mendorong air untuk mengikis sedimen dan mengangkut sedimen keluar dari waduk ${ }^{4)}$. Berdasarkan hal tersebut, untuk menunjang kebutuhan operasional dan pemeliharaan PLTA Musi, dibutuhkan pendekatan secara dini untuk melihat pola sedimentasi yang terjadi. Pendekatan karakteristik dan pola penumpukan sedimen di Bendung PLTA Musi ini dilakukan dengan simulasi pemodelan numerik hidrodinamika dan aliran sedimen dengan menggunakan perangkat lunak Surface Modeling System 8.01, untuk memprediksi besar volume sedimen, sebaran distribusi sedimen, pola endapan dan gerusan, yang berpotensi terkumpul di lokasi bendung maupun reservoir PLTA Musi. Pada dasarnya program SMS (Surface Water Modelling System) lebih banyak digunakan untuk perhitungan perubahan dasar saluran bergerak (movable bed). Perhitungan dasar tidak bergerak (fix bed) dapat dilakukan dengan menjadikan ketebalan lapisan tererosi sama dengan nol, sehingga dalam perhitungan program akan mengasumsikannya sebagai dasar batuan tidak tererosi (non-erodible rock). Jenis sedimen yang dapat diaplikasikan ke dalam model adalah butiran non-cohesive (sand), dan cohesive (clay) ${ }^{5)}$. Program dapat digunakan untuk pemodelan aliran sedimen tetap dan tidak tetap, tetapi jenis butiran yang dipakai adalah satu jenis saja (effective grain size). Muatan sedimen yang masuk ke dalam model adalah dalam bentuk konsentrasi sedimen $\left(\mathrm{kg} / \mathrm{m}^{3}\right)^{6}$. Penelitian ini bertujuan untuk mengindentifikasi pola sebaran serta beban sedimentasi yang terjadi pada Bendung dan Reservoir PLTA Musi, sehingga dapat diketahui kebutuhan operasi dan pemeliharaan Bendung. 


\subsection{Model SMS 8.01}

Surface Modeling System (SMS) adalah paket program untuk model suatu profil aliran dan analisisnya. Paket program ini memakai metode dua (2) dan tiga (3) dimensi persamaan finite element dan finite diferrent, satu dimensi untuk perhitungan analisis back water. Masing-masing model numerik didesain untuk menspesifikasikan masalah beberapa perhitungan hidrodinamika, seperti elevasi permukaan air dan kecepatan aliran. Perhitungan analisis lainnya adalah mekanika gelombang, seperti ketinggian dan arah gelombang. Kemudian bagian lain yang dapat dianalisis adalah penyebaran polutan atau penyebaran konsentrasi sedimen suspended load. Beberapa sub-sub model tersebut dapat menghitung kondisi steady state dan dynamic, sementara beberapa hal lain hanya dapat menganalisis kondisi steady state serta kondisi aliran superkritis, atau hanya subkritis saja. Finite element (mesh), finite different (grid), atau cross section, sepanjang nilai batas yang dibutuhkan dalam analisis semuanya dibangun melalui paket program SMS 8.01 ${ }^{[5]}$. Model numerik paket ini dalam perhitungannya menghasilkan suatu keluaran hasil analisis berupa elevasi muka air, kecepatan aliran, konsentrasi penyebaran polutan, sedimen konsentrasi. Kelebihan dari paket program SMS 8.01 adalah dapat menampilkan hasil berupa animasianimasi yang berkaitan dengan hasil analisis perhitungannya.

\subsection{Persamaan Pembangun}

Modul RMA2 memecahkan persamaan kontinuitas dan momentum yang menyebabkan arus menggunakan metode elemen batas (finite element) yang terdapat pada modul SMS 8.01, dimana persamaan kontinuitas dan momentum tersebut adalah sebagai berikut ${ }^{7)}$ :

$\frac{\partial(\mathrm{h}+\eta)}{\partial \mathrm{t}}+\frac{\partial q_{x}}{\partial x}+\frac{\partial q_{y}}{\partial y}=0$

$\frac{\partial q_{x}}{\partial \mathrm{t}}+\frac{\partial u q_{x}}{\partial x}+\frac{\partial v q_{x}}{\partial y}+\frac{1}{2} g \frac{\partial(\mathrm{h}+\eta)^{2}}{\partial x}=\frac{\partial}{\partial x} D_{x}+\frac{\partial q_{x}}{\partial x}+\frac{\partial}{\partial y} D_{y} \frac{\partial q_{x}}{\partial y}+f q_{y}-\tau_{b x}+\tau_{w x}+\tau_{S x}$

$\frac{\partial q_{y}}{\partial \mathrm{t}}+\frac{\partial u q_{y}}{\partial x}+\frac{\partial v q_{y}}{\partial y}+\frac{1}{2} g \frac{\partial(\mathrm{h}+\eta)^{2}}{\partial y}=\frac{\partial}{\partial x} D_{x}+\frac{\partial q_{y}}{\partial x}+\frac{\partial}{\partial y} D_{y} \frac{\partial q_{y}}{\partial y}+f q_{y}-\tau_{b y}+\tau_{w y}+\tau_{s y}$

Dimana, $\mathrm{h}$ adalah kedalaman perairan, $\eta$ adalah elevasi muka air terhadap kedalaman perairan, $\mathrm{t}$ adalah waktu, $\mathrm{q}_{\mathrm{x}}$ adalah aliran per unit lebar yang paralel dengan sumbu $\mathrm{x}, \mathrm{q}_{\mathrm{y}}$ adalah aliran per unit lebar yang paralel dengan sumbu y, u \& v adalah kecepatan arus lateral rata-rata arah $\mathrm{x}$ dan $\mathrm{y}, \mathrm{g}$ adalah percepatan gravitasi bumi, $\mathrm{f}$ adalah parameter coriolis, $\tau_{\mathrm{bx}}$ dan $\tau_{\mathrm{by}}$ adalah gaya geser lateral pada dasar, yang dihitung menggunakan hukum standar gesekan kuadratik. $\tau_{\mathrm{Sx}}$ dan $\tau_{\mathrm{Sy}}$ adalah tegangan pada muka air akibat gelombang. $\tau_{\mathrm{wx}}$ dan $\tau_{\mathrm{wy}}$ adalah tegangan pada muka air. Komponen kecepatan $u$ dan $v$ diperoleh menggunakan persamaan berikut ${ }^{[7]}$ :

$u=\frac{q_{x}}{h+\eta}$

$v=\frac{q_{y}}{h+\eta}$ 


\section{METODE}

Metode yang digunakan dalam penelitian ini adalah menggunakan software Surface Modeling System dengan modul RMA2 dan SED. Dalam pemodelan sedimentasi tahap pertama adalah pemodelan arus dilakukan untuk mengetahui pola pergerakan arah dan kecepatan arus di sekitar Sungai Musi. Pemodelan arus menggunakan syarat batas (boundary condition) data debit sungai yang diperoleh dari pengolahan analisis data curah hujan sebagaimana ditunjukan pada tabel 1. Adapun lingkup pekerjaannya adalah sebagai berikut ini:

a. Pengolahan data tinggi muka air.

b. Kalibrasi data arus tinggi muka air pengamatan dan simulasi.

c. Analisis deskripsi arah dan kecepatan arus simulasi.

d. Analisis deskripsi arah dan simulasi sedimentasi.

Area studi berada di sekitar Sungai Musi, adapun peta area studi dapat dilihat pada gambar 1 berikut ini:

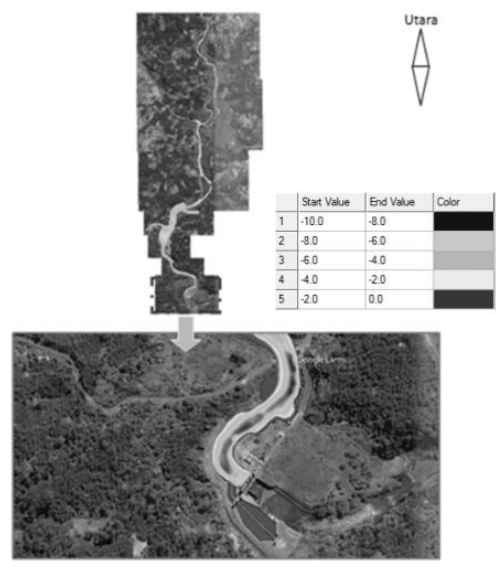

Gambar 1. Orientasi lokasi studi dan Bendung PLTA Musi

\subsection{Syarat Batas Model}

Syarat batas model yang digunakan pada penelitian ini yaitu sebagai berikut:

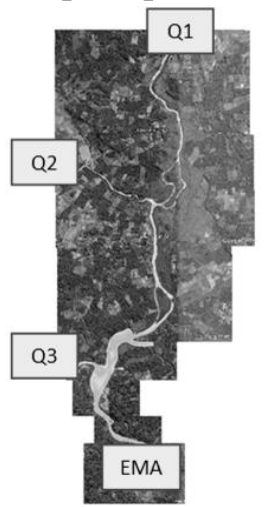

Gambar 2. Posisi penetapan syarat batas model hidrodinamika 
1) Data elevasi muka air.

Data elevasi muka air digunakan sebagai syarat batas hilir pada lokasi water intake. Data elevasi muka air didapatkan dari hasil pengukuran lapangan [m] disajikan pada gambar 3. Adapun data elevasi muka air yang telah dinolkan nilai rata - rata nya adalah sebagai berikut ini.

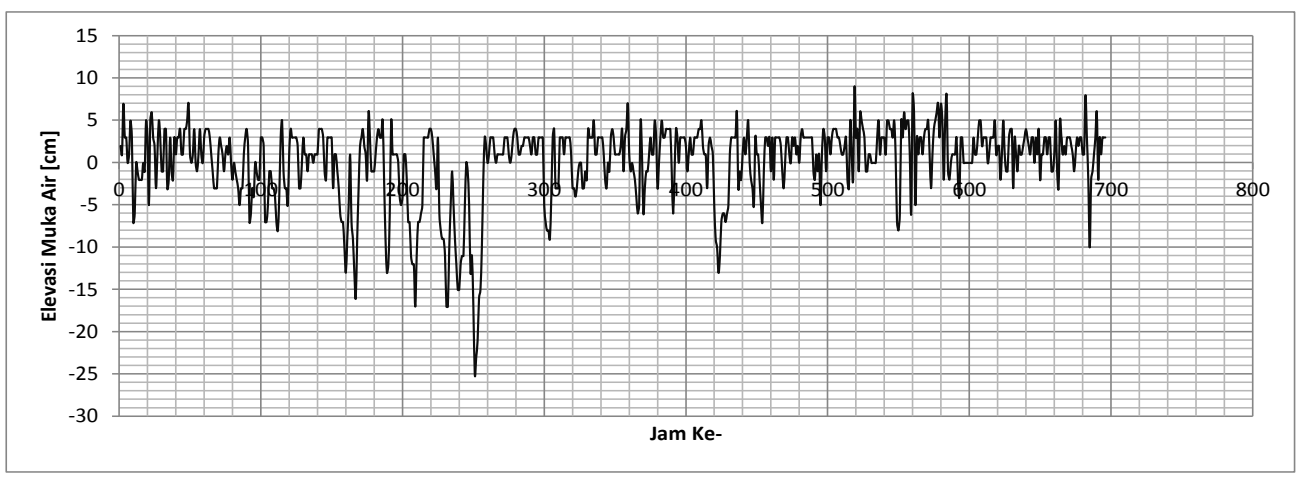

Gambar 3. Data elevasi muka air pada syarat batas hilir

2) Data debit sungai.

Data debit sungai digunakan sebagai syarat batas hidrodinamika. Pemodelan hidrodinamika dilakukan dalam dua simulasi dengan perbedaan data debit syarat batas. Simulasi 1 menggunakan data debit andalan pada bulan November-Desember sesuai waktu pengukuran elevasi muka air di intake PLTA Musi, kemudian simulasi 2 menggunakan data debit banjir rata-rata periode ulang 25 tahunan. Data debit sungai yang digunakan berasal dari hulu sungai (Q1), anak sungai 1 (Q2) dan anak sungai 2 (Q3), dan diberikan seragam untuk seluruh domain model tetapi bervariasi terhadap waktu disajikan pada tabel 1 berikut:

Tabel 1. Data debit bulan November dan Desember

\begin{tabular}{ccccc}
\hline \multirow{2}{*}{ Nama Syarat Batas } & Luas Area & \multicolumn{3}{c}{ Debit Andalan (m3/s) } \\
\cline { 3 - 5 } & DAS $(\mathrm{km} 2)$ & Nov & Des & Rata-rata \\
\hline Q1 (Hulu) & 517.220 & 39.916 & 38.622 & 37.769 \\
Q2 (Anak Sungai1) & 55.12 & 3.934 & 4.116 & 4.025 \\
Q3 (Anak Sungai2) & 1.68 & 0.120 & 0.125 & 0.123 \\
\hline
\end{tabular}

3) Data Sedimen

Data konsentrasi sedimen digunakan sebagai syarat batas pemodelan SED2D (sedimen). Data konsetrasi sedimen didapatkan berdasarkan data pengukuran lapangan [gr/l] pada tabel 2, dan diberikan seragam untuk seluruh domain model tetapi bervariasi terhadap waktu.

Tabel 2. Data sedimen layang pada syarat batas Q1, Q2 dan Q3

\begin{tabular}{ccc}
\hline STA & Syarat Batas (BC) & Kadar Sedimen Layang $(\mathrm{gr} / \mathrm{l})$ \\
\hline STA-01 & Q1 & 0.166 \\
STA-02 & Q2 & 0.051 \\
STA-03 & Q3 & 0.028 \\
\hline
\end{tabular}




\subsection{Verifikasi Kecepatan Arus Rata-rata}

Hasil model harus diverifikasi agar dapat diterima dari sudut pandang teknis. Untuk tujuan ini kita menggunakan rata kecepatan dengan rumus ${ }^{[7]}$ :

$$
v=\frac{Q}{A}
$$

Dimana, $\mathrm{v}=$ kecepatan rata - rata $(\mathrm{m} / \mathrm{s}), \mathrm{Q}=$ debit sungai $\left(\mathrm{m}^{3} / \mathrm{s}\right), \mathrm{A}=$ cross section area $\left(\mathrm{m}^{2}\right)$. Dalam kasus ini, kondisi debit pada kondisi batas hulu yaitu Q1,Q2 dan Q3, sedangkan luasan penampang (cross section area) yang diukur yaitu L1, L2 dan L3. Oleh karena itu, dengan rumus di atas didapat nilai kecepatan arus rata-rata pada tabel 3 sebagai berikut:

Tabel 3. Nilai kecepatan arus rata-rata pada setiap syarat batas

\begin{tabular}{ccccc}
\hline Nama Syarat Batas & $\begin{array}{c}\text { Debit } \\
\text { rata-rata } \\
(\mathrm{m} 3 / \mathrm{s})\end{array}$ & $\begin{array}{c}\text { Luas } \\
\text { Penampang } \\
(\mathrm{m} 2)\end{array}$ & $\begin{array}{c}\text { Kecepatan } \\
\text { Arus }(\mathrm{m} / \mathrm{s}) \\
\text { Aktual }\end{array}$ & $\begin{array}{c}\text { Kecepatan Arus } \\
(\mathrm{m} / \mathrm{s}) \text { Model }\end{array}$ \\
\hline Q1 (Hulu) & 37.769 & 99.40 & 0.36 & 0.39 \\
Q2 (Anak Sungai1) & 4.025 & 67.20 & 0.06 & 0.07 \\
Q3 (Anak Sungai2) & 0.123 & 56.77 & 0.01 & 0.01 \\
\hline
\end{tabular}

\subsection{Kalibrasi Elevasi Muka Air}

Kalibrasi elevasi muka air dilakukan untuk mendapatkan model yang sesuai dengan kondisi lapangan yaitu dengan cara membandingkan data elevasi muka air hasil simulasi model dengan data hasil survei lapangan. Data elevasi muka air hasil simulasi model menggunakan data dari lokasi yang sama dengan lokasi pengamatan elevasi muka air saat survey. Harga error tidak boleh melebihi $20 \%$. Adapun persaman untuk memperoleh harga error adalah ${ }^{[7]}$ :

$$
\text { Error }=\frac{1}{\mathrm{~N}}\left[\sum_{\mathrm{i}=1}^{\mathrm{N}}\left|\frac{\dot{\mathrm{x}}_{\mathrm{i}}-\mathrm{x}_{\mathrm{i}}}{\mathrm{TP}}\right|\right] * 100 \%
$$

Dimana, $\mathrm{N}=$ timestep, $\dot{\mathrm{X}} \mathrm{i}=$ hasil pemodelan, $\mathrm{xi}=$ data lapangan, $\mathrm{TP}=$ tunggang pasut (lapangan) grafik perbandingan elevasi muka air data lapangan dengan elevasi muka air (EMA) hasil simulasi model dapat dilihat pada tabel 4 berikut:

Tabel 4. Harga error kalibrasi elevasi muka air

\begin{tabular}{cc}
\hline Parameter Statistik & Nilai Statistik \\
\hline Min (Lapangan) & 0.75 \\
Max (Lapangan) & 1.09 \\
Min (Model) & 0.77 \\
Max (Model) & 1.12 \\
( (Xi-Xi) & -0.92 \\
Tunggang Ema & 0.34 \\
N (Jumlah Data) & 696 \\
Error (\%) & $0.4 \%$ \\
\hline
\end{tabular}




\section{PEMBAHASAN DAN DISKUSI}

\subsection{Model Hidrodinamika Arus}

Berdasarkan pengamatan pemodelan arus, kecepatan arus yang terjadi bervariasi pada setiap tikungan dan kedalaman sungai. Pada area model terdapat beberapa spot dengan kecepatan arus cukup tinggi dan biasanya mendapatkan nilai gesekan dasar (bed shear stress) yang tinggi dibandingkan dengan area lainnya dan berpotensi terjadi gerusan. Fenomena ini tidak dapat diamati secara langsung. Salah satu metode penyederhanaannya adalah dengan pemodelan ${ }^{8}$. Kemudian untuk memudahkan analisis maka dilakukan pemisahan segmen disajikan pada gambar 5 . Hasil pemodelan arus di area sungai dapat dilihat pada gambar 5 berikut ini:

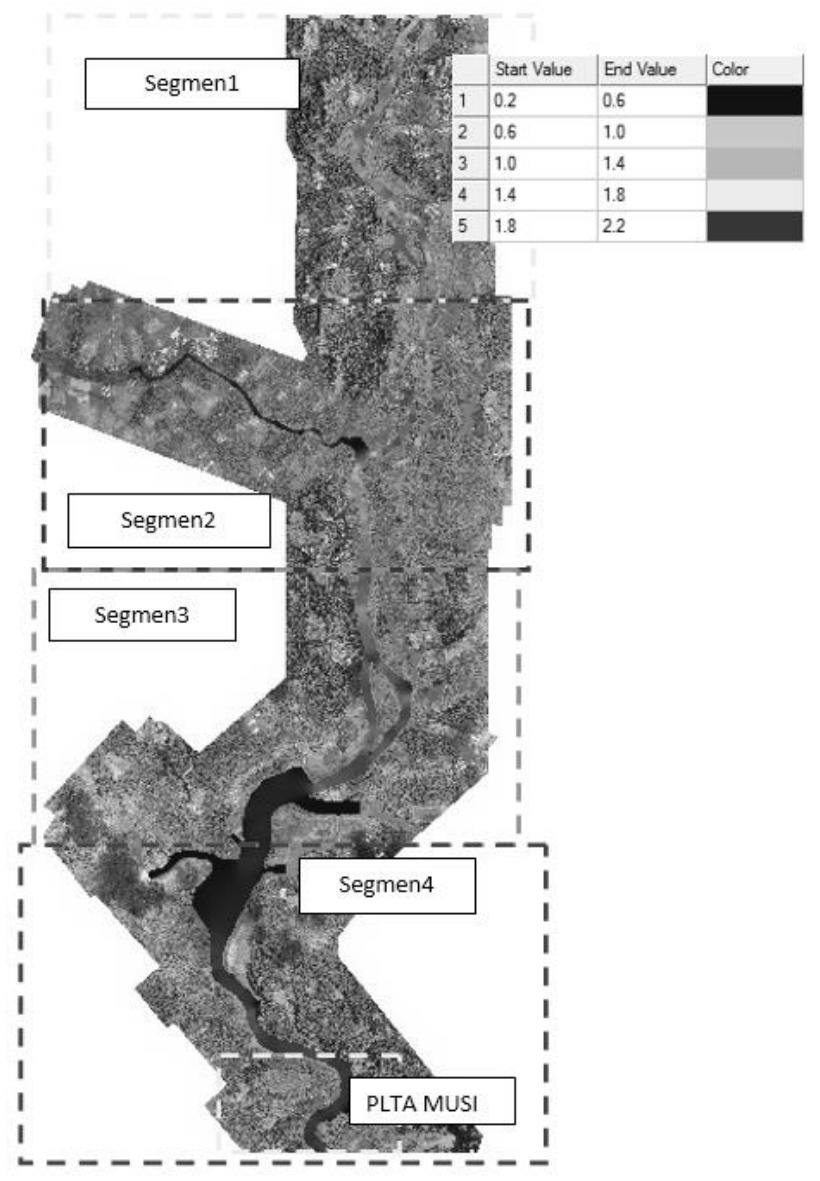

Gambar 5. Pola arah arus pada area sungai eksisting (satuan dalam m/s)

Berdasarkan hasil pemodelan hidrodinamika arus sungai terdapat beberapa segmen lokasi yang memiliki nilai kecepatan arus yang relatif tinggi, salah satu segmen tersebut adalah pada segmen 1 dan segmen 2. Kecepatan arus pada lokasi segmen 1 mencapai 0.54 $\mathrm{m} / \mathrm{s}$. Kecepatan arus pada lokasi segmen 2 mencapai $0.61 \mathrm{~m} / \mathrm{s}$. Kecepatan arus pada lokasi segmen 3 mencapai $0.43 \mathrm{~m} / \mathrm{s}$. Kecepatan arus pada lokasi segmen 4 mencapai $0.25 \mathrm{~m} / \mathrm{s}$, sebagaimana disajikan pada gambar 6 . 


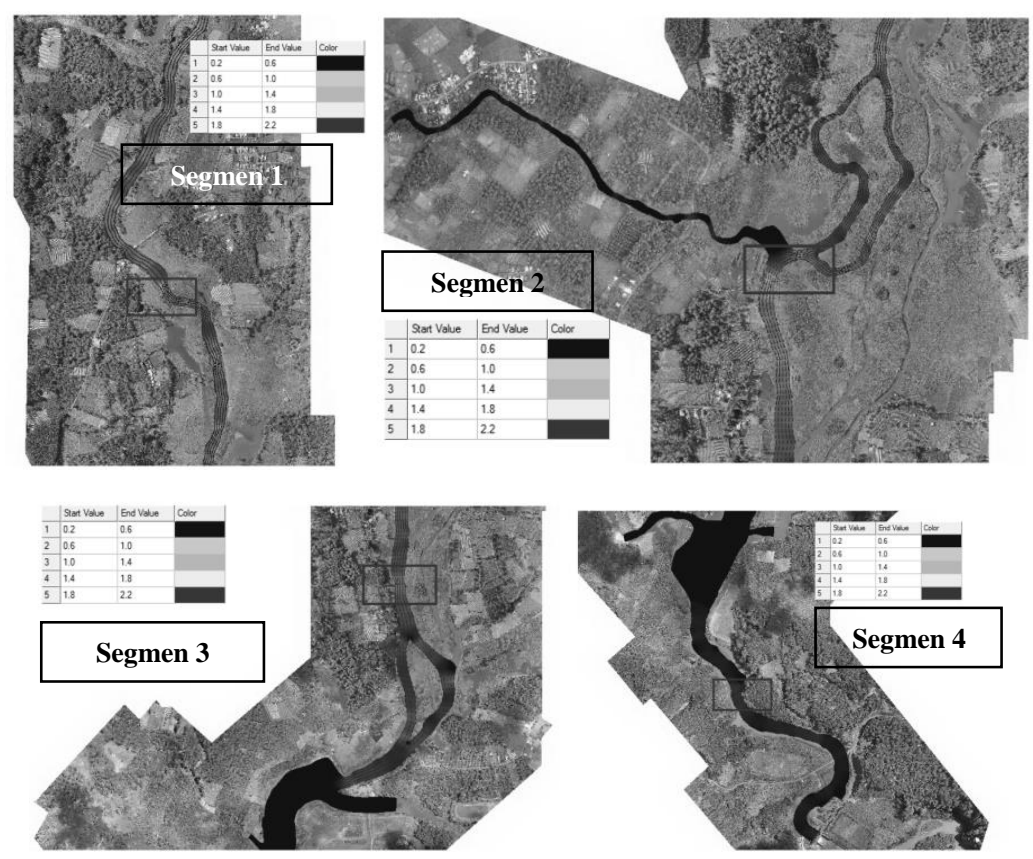

Gambar 6. Pola arah arus pada segmen 1,2,3 dan 4 di area sungai eksisting

Pola arus pada gambar 6 menunjukan bahwa karakteristik dari segmen 1 sampai dengan 4 sangat dipengaruhi oleh morfologi sungai dan lebar sungai. Kecepatan arus ini sebagai penggerak utama proses sedimentasi menuju bendung PLTA Musi, namun karena lokasi sungai yang berkelok maka beberapa sedimen terperangkap dan menumpuk kemudian menjadi sebuah daratan baru atau yang disebut dengan delta. Ini adalah permasalah yang cukup serius karena dalam kondisi hujan besar dan banjir, maka sedimen yang membentuk delta tersebut akan tergerus kembali dan kemudian akan bertumpuk di badan bendung PLTA Musi. Pola dari pergerakan arus yang sudah dimodelkan dapat memperlihatkan dan memitigasi terjadinya delta-delta baru dengan melakukan pemeliharaan sungai secara rutin serta membangun perangkap sedimen lainnya.

\subsection{Hubungan Antara Kecepatan Arus dan Bed Shear}

Semakin besar nilai kecepatan arus pada umumnya cenderung meningkatkan nilai gesekan permukaan dasar (bed shear) antara masa air yang bergerak pada suatu perairan sebagaimana disajikan pada gambar 7. Tingginya nilai bed shear juga berhubungan dengan tingginya erosi pada suatu perairan. Hal tersebut dapat dilihat dari hasil simulasi pada gambar 7. Hubungan antara bed shear terhadap kedalaman lapisan sedimen adalah semakin bertambahnya kedalaman maka kecepatan kritis yang dibutuhkan juga semakin besar, semakin dengan bertambahnya kedalaman maka berat jenis basah dan berat jenis kering yang dihasilkan semakin besar ${ }^{9}$ ). Bedasarkan diagram Hjulstrom proses erosi sedimen sangat memerlukan kecepatan arus yang lebih besar untuk dapat mengangkat sedimen, yaitu jenis pasir dibutuhkan kecepatan $>10 \mathrm{~m} / \mathrm{s}$ untuk dapat mengerosinya, namun untuk dapat mengerosi lempung diperlukan kecepatan arus $>100 \mathrm{~m} / \mathrm{s}^{10}$. Hal ini 
terjadi karena sedimen dengan jenis lempung memiliki sifat kohesif yang menyebabkan partikel menjadi terikat satu sama lain, namun jika sedimen belum terikat kecepatan arus yang dibutuhkan untuk mengrosinya berkisar antara $8-10 \mathrm{~m} / \mathrm{s}^{[10]}$.

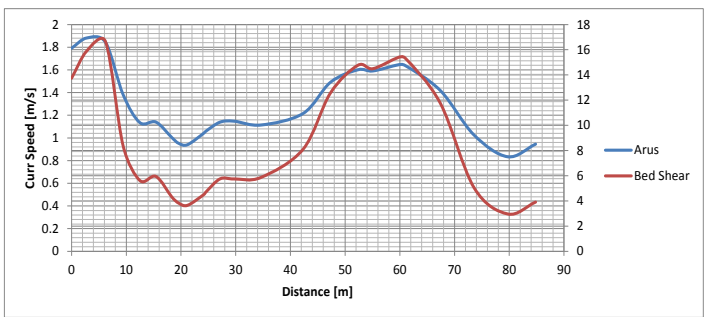

(a)

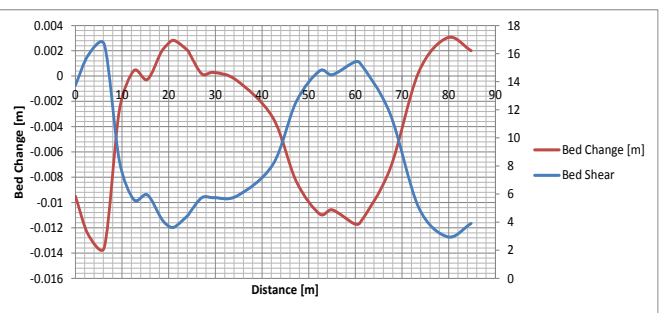

(b)

Gambar 7. (a) Hubungan antara kecepatan arus; (b) Hubungan bed shear dan perubahan kedalaman

\subsection{Pola Aliran Sedimen berdasarkan Bed Level Change}

Pola perubahan kedalaman sungai yang diperoleh dari hasil simulasi model menggunakan gaya pembangkit debit sungai. Perubahan kedalaman pada sungai diketahui berdasarkan perubahan ketebalan dasar sungai. Perubahan dasar sungai umumnya mengalami sedimentasi (pendangkalan) dan erosi (pengikisan). Hasil pemodelan dari Modul SED2D ini adalah konsentrasi sedimen pada suatu lokasi dari waktu ke waktu serta perubahan kedalaman sungai akibat sedimentasi. Hasil perubahan kedalaman perairan dan laju sedimentasi selama simulasi disajikan pada gambar 8 di bawah ini:

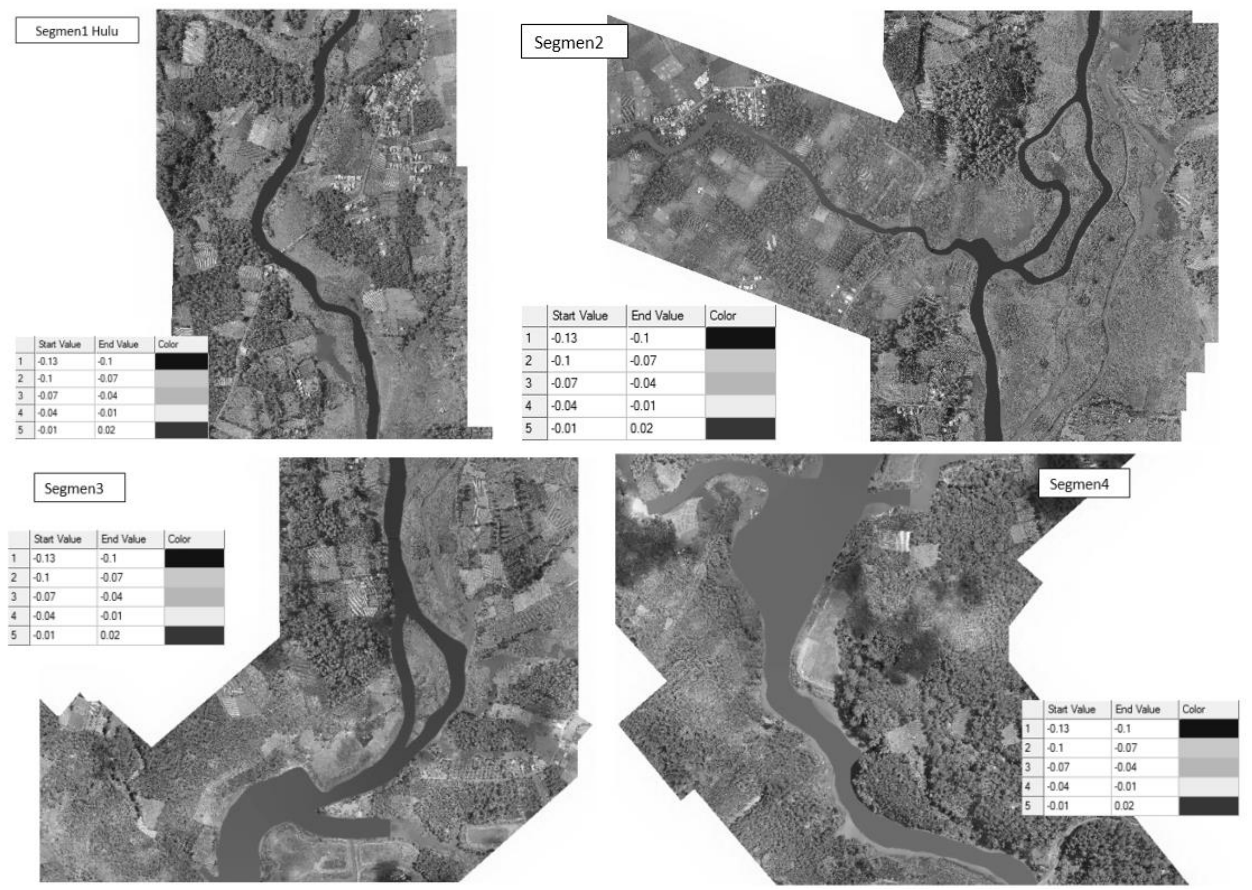

Gambar 8. Perubahan kedalaman pada setiap segmen 1, 2, 3 dan 4 di area sungai eksisting selama simulasi (1 bulan) (satuan dalam meter) 
Nilai perubahan kedalaman cenderung negatif yang menandakan telah terjadi erosi pada sisi dasar sungai sedangkan nilai positif menandakan terjadi sedimentasi dimana terjadi penambahan kedalaman sungai. Kemudian ditinjau secara mendetail perubahan kedalaman berdasarkan setiap segmen observasi. Didapatkan nilai volume sedimentasi selama simulasi pada segmen 1 didapat $1390.16 \mathrm{~m}^{3}$, segmen 2 didapat $1681.67 \mathrm{~m}^{3}$, segmen 3 didapat $2160.85 \mathrm{~m}^{3}$ dan segmen 4 didapat $1202.14 \mathrm{~m}^{3}$. Kemudian sedimentasi di bendung PLTA Musi didapatkan $211.588 \mathrm{~m}^{3}$ untuk simulasi satu bulan.

\section{KESIMPULAN}

Kesimpulan yang didapatkan dari hasil penelitian yaitu sebagai berikut:

a. Berdasarkan hasil pengamatan lapangan didapatkan jenis sedimen dasar didominasi lanau (silt) dan pasir (sand) dengan nilai kadar sedimen layang tertinggi $0.166 \mathrm{gr} / \mathrm{l}$.

b. Pola pergerakan arus dari setiap segmen 1,2,3, dan 4 memiliki nilai yang berbedabeda dengan nilai tertinggi pada segmen 2 yaitu sebesar $0.61 \mathrm{~m} / \mathrm{s}$. Hal ini dikarenakan segmen 2 terdapat pada posisi tiga cabang sungai.

c. Total sedimentasi hasil simulasi satu bulan didapatkan nilai volume sedimentasi pada segmen 1, yaitu $1390.16 \mathrm{~m}^{3}$; segmen 2, yaitu $1681.67 \mathrm{~m}^{3}$; segmen 3, yaitu $2160.85 \mathrm{~m}^{3}$; dan segmen 4, yaitu $1202.14 \mathrm{~m}^{3}$. Variasi nilai volume sedimentasi ini dipengaruhi oleh beberapa factor, salah satunya pergerakan arus yang dapat mempengaruhi besaran nilai gesekan dasar perairan, sehingga didapatkan nilai besaran volume sedimen pada bendung PLTA Musi $211.588 \mathrm{~m}^{3}$ selama simulasi satu bulan. Jika dikalikan dalam satu tahun maka didapatkan volume sedimen sebesar $2539.056 \mathrm{~m}^{3}$.

\section{UCAPAN TERIMA KASIH}

Penulis mengucapkan terima kasih kepada Unit Layanan PLTA Musi, PT PLN (Persero), Kabupaten Kepahiang, Provinsi Bengkulu dan LKFT UGM yang bekerjasama dengan PT. PUMA Engineering yang telah membantu dalam penelitian ini serta semua pihak yang sudah membantu dalam kelancaran penelitian yang dilakukan.

\section{DAFTAR PUSTAKA}

1) Irwan, A., Wicaksono, A., \& Khairin, F. A. (2020). Identifikasi Distribusi Beban Sedimentasi pada Intake DAM dan Reservoir PLTA (Studi Kasus: PLTA Cirata, Purwakarta-Jawa Barat). Journal Of Applied Science (JAPPS), 2(1), 022-030.

2) Adnan, M., \& Muflihin, M. (2018). Pengaruh Variasi Kemiringan Flushing Conduit Terhadap Volume Penggelontoran Sedimen Di Waduk (Uji Eksperimental). Teknik Hidro, 11(2), 71-81.

3) Khairul, A., Halim, A., \& Barchia, M. F. (2014). Rainfall analysis for estimation of peak discharge and soil erosion on the catchment area of Musi Hydro-Power Plant, Bengkulu Indonesia. International Proceedings of Chemical, Biological and Environmental Engineering (IPCBEE), 63, 83-87.

4) Dwiguna, M. A., Dermawan, V., \& Wicaksono, P. H. (2018). Pemodelan Flushing Sedimen Bendung Lodoyo dengan Menggunakan Sediment Simulation In Intake with Multiblock Option (SSIIM 2). Jurnal Mahasiswa Jurusan Teknik Pengairan, 2(1), 24.

5) Anonim. 2003. Surface Water Modeling System Tutorial Version 8.1. Brigham Young University Environmental Modeling Research Laboratory. 
6) Irwan, A., \& Yuanita, N. (2018). Studi Transportasi Sedimen pada Alur Pelayaran di Muara Sungai Donan, Cilacap-Jawa Tengah. Seminar Nasional Teknik Sipil 2018.

7) Aquaveo, 2014, SMS User Manual (v11.1), Utah: Aquaveo.

8) Wiyono, A., Nugroho, J., Widyaningtias, W., \& Zaidun, E. R. (2011). Perbandingan Gerusan Lokal yang Terjadi di Sekitar Abutment Dinding Vertikal Tanpa Sayap dan dengan Sayap pada Saluran Lurus, Tikungan $90^{\circ}$, dan $180^{\circ}$ (Kajian Laboratorium). Jurnal Teknik Sipil, 18(1), 41-54.

9) Marvin, M., \& Pranoto, W. A. (2019). Studi Debit Angkutan Sedimen Dasar Sungai Citarum Dengan Rumus Eintein's, Shields, Schoklitsch's Dan Laboratorium. JMTS: Jurnal Mitra Teknik Sipil, 2(4), 221-228.

10) Satria, F. W., Saputro, S., \& Marwoto, J. (2017). Analisa Pola Sebaran Sedimen Dasar Muara Sungai Batang Arau Padang. Journal of Oceanography, 6(1), 47-53. 